Research Paper

\title{
Examining stakeholder group specificity: An innovative sustainable tourism approach
}

\author{
Anne Hardy ${ }^{\mathrm{a}, *}$, Leonie J. Pearson ${ }^{\mathrm{b}}$ \\ a Tasmanian School of Business and Economics, University of Tasmania, Private Bag 84, Sandy Bay, Tasmania 7000, Australia \\ ${ }^{\mathrm{b}}$ Institute for Governance and Policy Analysis, University of Canberra, ACT 2601, Australia
}

\section{A R T I C L E I N F O}

\section{Keywords:}

Stakeholder attitudes

Q- methodology

Sustainable tourism

Tasmania

\begin{abstract}
A B S T R A C T
It is now widely accepted that stakeholder consultation is necessary for sustainable tourism development to occur and that a variety of stakeholder groups occur. In tourism, these groups are often referred to as locals, operators, community members and those in regulatory positions. However, a divide exists within the literature. One cluster of literature suggests that individual stakeholders possess attitudes that are specific to their group. Another cluster of research suggests that individual stakeholders' attitudes do not always align with their stakeholder groups. This paper responds to this dichotomy and utilises the Q methodology to assess the attitudes of stakeholders in the Tarkine region of Tasmania, Australia. The research highlights that individual stakeholders' attitudes do not always align to their stakeholder group when considering sustainable tourism development and that responsive methods are required to ensure adequate stakeholder involvement. In doing so, it challenges the long-held notion of stakeholder group specificity.
\end{abstract}

\section{Introduction}

Stakeholders have been defined as 'any group or individual who can affect or is affected by the achievement of an organisation's objectives' (Freeman, 1984, p. 46). The identification and involvement of stakeholders in tourism management decisions is now widely encouraged within tourism literature (Cheng, Hu, Fox, \& Zhang, 2012; Hardy \& Beeton, 2001; Jamal \& Getz，1999; Sautter \& Leisen, 1999; Yuksel, Bramwell, \& Yuksel, 1999). Traditionally, stakeholder groups have been identified as behavioural groups of people within the broader tourism system, such as operators, tourists, residents, those in regulatory positions and tourists. A large amount of research into stakeholder groups' attitudes towards tourism exists, often consisting of studies that explore one stakeholder group at a time (Hardy \& Beeton, 2001). However, when comparisons of stakeholders groups' attitudes have been made, there is a dichotomy evident within the literature. One body of literature suggests that different stakeholders possess attitudes that are specific to their group (Byrd, Bosley, \& Dronberger, 2009; Timur \& Getz, 2009; Hardy, 2005). Another body of recent research suggests that stakeholder identities do not necessarily conform to the same clusters of attitudes (Hunter, 2013). This paper aims to critique the alignment of individual stakeholders' attitudes with their traditionally defined stakeholder groups, with respect to sustainable tourism development. The objectives of this paper are to:
1. Present a pictorial $Q$ method analysis in the Tarkine region of Tasmania, Australia, in order to critically assess whether stakeholders' attitudes align with their traditionally defined groups in relation to sustainable tourism development;

2. Contribute to theory regarding the identification of stakeholder groups and the alignment of individual stakeholders' attitudes with their traditionally defined stakeholder groups, and the role of stakeholder involvement in planning for sustainable tourism;

3. Identify the key factors that concern stakeholders, in relation to future tourism development in the Tarkine region of Australia.

\section{Stakeholder theory}

Stakeholder theory and its practical application in management is now a readily accepted approach for managing businesses, regional development and ensuring that tourism is developed in a responsive and appropriate manner (Bornhorst, Ritchie \& Sheehan, 2010; Byrd \& Gutske, 2007; Clarkson, 1995; Grimble \& Wellard, 1997; Hunter, 2013; Jamal \& Getz, 1999). Within tourism, Byrd (2007) and Hardy and Beeton (2001) argue that the assumption that all stakeholders have a right to participate if they have an interest in an organisation or an issue, is essential. Both posit that stakeholder involvement must begin with recognition of stakeholders and make allowance for them to make informed and conscious decisions about the

\footnotetext{
* Corresponding author.

E-mail addresses: Anne.Hardy@utas.edu.au (A. Hardy), leonie.pearson@canberra.edu.au (L.J. Pearson).
} 
development of tourism at a specific destination. However, the reality is that stakeholders are not always recognised and their perspectives are not always taken into account by managers (Byrd et al., 2009; Currie, Seaton, and Wesley, 2009). Arguably there is a greater need to understand the barriers and opportunities for stakeholder involvement (Woodland and Acott, 2007). This requires consultation of a wide range of stakeholders in an in-depth manner, which is time-consuming and expensive (Bramwell \& Sharman, 1999; Clarkson, 1995; Hardy \& Beeton, 2001; Yuksel et al., 1999) but is a process that will ultimately reduce the potential for conflicts, reduce power imbalances and is more politically legitimate. Arguably, stakeholder recognition involves several elements, including deciding who is may be defined as a stakeholder, identifying stakeholders' power and influence, and deciphering stakeholders' needs. Regarding the first point, there has been much discussion over who a stakeholder is with two emergent approaches (Byrd, 2007). The first is a normative moral approach, akin to that proposed by Donaldson and Preston (1995) whereby consideration is given to all tourism stakeholder groups without one being given priority over the other. This furthers broad definitions of the term by authors such as Freeman (1984). The second approach considered by Byrd (2007) has synergies with the classical notion of stakeholder management, where a central agency assesses the interests of stakeholders, then decides who shall be consulted with and develops policy based upon their power (see Clarkson, 1995; and Grimble \& Wellard, 1997). This approach has been robustly criticised as favouring the 'traditional stakeholder elite' (Wesley \& Pforr, 2010). They argue for more transparent and inclusive processes and practices that will ensure that traditionally excluded stakeholders are involved in a meaningful way.

The second element of stakeholder recognition involves deciphering stakeholders' power and influence. While power and predictability predictors matrixes have been developed (see Markwick, 2000; Newcombe, 2003), these models have been criticised as being inherently static and unable to acknowledge that stakeholder groups can suddenly become influential (Hardy, Wickham, \& Gretzel, 2013; Vernon, Essex, Pinder, \& Curry, 2005). Today, this is primarily a result of new technologies such as social media, which can facilitate communication and support the empowerment of neglected stakeholder groups (Hardy et al., 2013). This issue was also raised, prior to the rise of internet, by Healey (1997), who argued that 'stakeholder analysis needs to be conducted in an explicit, dynamic and revisable way as stakeholders may change over time in their concerns'.

The third element of stakeholder recognition involves understanding stakeholders' needs. It is now commonly argued that stakeholders must be active participants in the tourism planning process (Byrd, 2007; Southgate \& Sharpley, 2002). Advocates suggest that understanding stakeholders' subjectivities can anticipate support or opposition for tourism development, that may then be incorporated into tourism planning and policy (Hunter, 2013; Kuvan and Akan, 2013; Phi, Dredge, \& Whitford, 2014). In reality, this can prove problematic as tourism is highly dynamic and its stakeholders have marked differences in opinions that stem from shared resources, conflicting opinions, and differentiating interests (Kuvan and Akan, 2013). Moreover, overlooking stakeholders in the first instance, or underestimating their power and interests can result in their needs being overlooked. Yet, despite these challenges, the desire to understand stakeholders' needs in tourism is a crucial component in achieving tourism that is sustainable in the long term.

\subsection{Stakeholder groups' attitudes}

Within stakeholder literature, the extent to which attitudes that are specific to stakeholder's behavioural group remains contentious. Some authors suggest that stakeholder attitudes are bound by their behavioural group. Illustrating this assumption, Byrd et al., (2009, p. 694), argued that there are four significant tourism stakeholder perspectives: tourists, residents, business operators and local government representatives. To other researchers, there is uncertainty. Getz and Timur (2005) suggested that while '...each stakeholder group has different goals and interests regarding [sustainable tourism development], there are some goals they share'. Similarly, Kuvan and Akan (2013) reported stakeholder groups sharing attitudes towards regarding the positive effects of tourism, along with wide discrepancies of attitudes across the groups, in relation to other issues. Other authors have explored his issue from the alternate angle: Ryan (2002) categorised stakeholders according to how they felt affected by tour operators, thus transcending the notion that attitudes are bound by stakeholders' behavioural group. Similarly, Hunter (2013) argued that stakeholder identities do not necessarily confirm to the same clusters of subjectivity.

In terms of achieving sustainable tourism, what remains largely uncontested is that if agreement between stakeholders groups occurs, there is an increased likelihood for collaboration (Andriotis, 2005; Sautter \& Leisen, 1999). Consequently, synergies and collaboration between stakeholder groups may be considered an indicator for the existence of sustainable tourism (Hardy \& Beeton, 2001; Hunter, 2013). However this process takes time and the challenges of achieving this when there are time constraints in place, has been noted (Phi et al., 2014). Moreover, if stakeholder groups have differing goals, conflict is likely to occur (Byrd et al., 2009) with situations such as 'dialogs of the deaf' arising, where stakeholders talk past one another and the focus shifts to their differences, rendering consensus even more difficult to achieve (Bohm, 1990; Van Eeten, 1999). The challenge for researchers whose goal is to work towards sustainable outcomes is to choose research methods that will sensitively draw out stakeholders groups' goals, concerns and expectations.

\subsection{The relationship between stakeholders and sustainable tourism}

Following the definition of sustainable development by the Bruntdland Commission (World Commission on Environment \& Development, 1987, p. 43) as that which 'meets the needs of the present without compromising the ability of future generations to meet with own needs', Driml (1996) described the phenomenon of Sustainable Activity X, whereby industries worked on the policy and definitional applications of the concept in their own sectors. In the years following early definitions, Moskwa, HigginsDesbiolles, and Gifford (2015) and Hardy (2005) argued that much sustainability discourse gave unequal attention to ecological imperatives. More recently, focus has been on socio-cultural aspects. This has led to suggestions that stakeholder management has numerous synergies with the notion of sustainable tourism. Sustainable tourism requires management of multiple issues, such as environmental preservation; economic health; ensuring guests are satisfied; and facilitating community wellbeing (Muller, 1994). Consequently, grassroots engagement with multiple stakeholders who represent these groups is posited as the first step towards sustainable tourism development (Dodds, 2007; Getz \& Timur, 2005; Hall, 2007; Hardy \& Beeton, 2001; Hardy, Beeton, \& Pearson, 2002; McCool, Moisey, \& Nickerson, 2001; Waligo, Clarke, \& Hawkins, 2013). However the practice of stakeholder involvement as a catalyst for achieving sustainable tourism is inherently problematic. The core tenets of sustainable tourism (e.g. economic wealth vs environmental conservation) and those who advocate them are arguably in conflict over resource use. The challenge therefore, is for researchers to find the common ground amongst these groups in order to progress towards sustainable tourism.

Within tourism literature, stakeholders have been traditionally identified groups such as the community, government departments, the private sector, the public sector (Hall \& Page, 1999) and, in later work, visitors (Hardy, 2005). Surprisingly, a literature review reveals that research that seeks to identify common ground across stakeholder groups is rare. Rather there is a trend in tourism research design to focus on the attitudes of only one individual stakeholder group at a time. Consequently, there has been much research into residents' attitudes towards tourism development (Choi \& Sirakaya, 2005; 
Jamal \& Getz, 1999; Miller, 2001) as well as research into tourists' attitudes (Ballanyne, Packer \& Falk, 2011; Lee \& Moscardo, 2005) and to a lesser extent, operators' attitudes (Becken, 2003) and regulators' attitudes (Godfrey, 1998). Only a limited amount of research has compared two stakeholder groups simultaneously, such as residents and tourists (Kuvan \& Akan, 2013; Puczko \& Ratz, 2000) or multiple stakeholder groups over the same issue (Byrd et al., 2009; Chen, 2014; Hardy \& Beeton, 2001; Marshall, Marshall, Abdullah, Rouphael, \& Ali, 2011). This dearth has been noted by Kuvan and Akan (2013) who suggested comparative analysis is necessary to identify areas of conflict and agreement and studies that involve more than two stakeholders groups are necessary to facilitate sustainable outcomes. Arguably, a concurrent assessment of multiple stakeholder groups is a more 'natural' fit for the normative approach of stakeholder management, articulated above. If the goal is to achieve sustainable tourism, research that explores the attitudes of multiple stakeholders groups' simultaneously, will allow researchers to explore and compare their attitudes towards current tourism issues. This approach has been advocated by many authors as the only mechanism for examining, monitoring and working towards sustainable tourism outcomes (Byrd, 2007; Byrd \& Gutske, 2007; Hardy \& Beeton, 2001; Sautter \& Leisen, 1999; Yuksel et al., 1999). The reasons concurrent assessments are not commonly conducted are unclear, but may relate to the financial cost and time required to undertake such multi-faceted studies.

\section{Methodological approaches for stakeholder studies in tourism}

Studies that explore the attitudes of stakeholders have taken a variety of perspectives. Popular approaches have included mixed methods including interviews and questionnaires (Timur \& Getz, 2009; Hardy \& Beeton, 2001); interviews (Yuksel et al., 1999); collaborative decision making (Bramwell \& Sharman, 1999); Delphi technique (Puczko \& Ratz, 2000); surveys and questionnaires (Byrd et al., 2009) and scales (Choi \& Sirakaya, 2005). However, these approaches are not always appropriate for communities where illiteracy or cultural norms are significant factors. Recently, authors have advocated for tourism to take a critical turn away from traditional positivist methods, towards more reflective and critical modes of inquiry that encourage flexible, democratic, reflexive and participatory approaches to research (Brookfield, 2005; Stergiou \& Airey, 2011; Westwood, Morgan, \& Pritchard, 2006). Within stakeholder research, there has been recognition of the need for more inclusive and bottom up approaches (Kuvan \& Akan, 2013; Wesley \& Pforr, 2010). Yet despite this recognition, there appear to be fewer examples of reflexive and participatory approaches in understanding the needs for stakeholders.

The need for this approach magnifies when considering the research environment in which researchers now operate. The issue of over researched residents and re-studying communities has been raised as a significant issue within the sociology and development literature (Sukarieh \& Tannock, 2013), but less so within tourism. Yet is a significant phenomenon that many tourism researchers would be familiar with, particularly in small regional areas or in destinations where significant events such as natural disasters, a large festival, politically significant events or structural economic reform have occurred.

These challenges and the debates regarding stakeholder involvement and sustainable tourism provided the conceptual and practical underpinning for this research, whose aim was to critique the alignment of individual stakeholders' attitudes with their traditionally defined stakeholder groups, with respect to sustainable tourism development.

\subsection{The Tarkine region, Tasmania, Australia}

The Tarkine is a remote region of Tasmania's West Coast that supports Australia's largest tract of cool temperate rainforest. As with many tourism regions, there is no definitive and universally agreed space that the name refers to. Rather, the Tarkine is considered as the north-west region of Tasmania between the Pieman River in the south, the Arthur River in the north, the Southern Ocean in the west and the Murchison Highway in the east. There is one reserve in the region, named the Savage River National Park (Tasmania Parks and Wildlife Service, 2014).

Landscapes within the Tarkine range from wild windswept beaches, through to extensive button grass plains with stunning vistas, to impressive rainforests and the widely photographed Callidendrous temperate rainforest (Kantvilas \& Jarman, 1993). The Tarkine has a wide range of nationally important cultural values associated with extensive historic Aboriginal occupation (Legge, 1928). The term 'Tarkine' emanates from the term 'Tarkineer', that was used to describe the Aboriginal tribes inhabiting western Tasmania before European colonisation (Department of the Environment, 2014).

The Tarkine has become well known in the last ten years for its emergent tourism opportunities. A number of tourism operators specialise in offering guided walks and accommodation throughout the region. For example, the township of Corinna has substantially increased visitation to the Tarkine region by offering forest walks and river cruises (Corinna, 2014). The newly opened Western Explorer Road is well publicised self-drive touring route.

Estimates are that approximately 180,931 domestic or overseas visitors came to the West Coast Region in 2013, of which the Tarkine forms a part (Tourism Tasmania, 2014). These figures represent a $12.6 \%$ growth from the previous year. Despite the growth in tourism, the region, like the rest of the state, faces socio-demographic challenges relevant for this research project. A recent study found functional adult literacy in Tasmania to be only 49\%, making it the lowest adult literacy in all states of Australia (Australian Bureau of Statistics, 2013). This meant that half of adult Tasmanians lack the literacy skills necessary to cope with the demands of everyday life and work, thus would be incapable of undertaking a self-completed questionnaire.

A further issue that required consideration for this research was the political environment of the region. The Tarkine is famous for environmental battles fought within the region. For decades, debates and protests regarding the development of roads for tourism, and the existence of forestry and mining have occurred. At the time of this research, there was much debate over the development of colloquially named Tasmanian Forest Peace Deal, which sought to decrease the amount of forestry and increase the protection of the Tarkine's forests. The demise of forestry, which had provided many residents with generations of income, was met with much angst and public debate over the future of the region. The project team explored this debate, plus others that had occurred in recent years, through the popular media and the narratives of management strategies related to the region. This background research revealed that the traditional stakeholder groups involved in debates and with an interest in tourism included: locals, aboriginal people, tourism operators, developers of other industries, those in regulatory positions, and members of groups who represented different factions within the community, (such as conservationists or those wishing to protect recreational activities such as four-wheel-drive clubs) (Cradle Coast Authority, 2008; Parks \& Wildlife Service, 2001). This issue, along with that of literacy, provided vital background information that informed the choice of methods.

\subsection{The $Q$ methodology}

Given the research aim was to assess the alignment of individual stakeholders' attitudes against their traditionally defined stakeholder groups with respect to sustainable tourism development, this research approach required an inclusive, innovative and non-written approach that would appeal to stakeholders and elicit the operant subjectivities of the participants. In particular, the requirement for an approach that would not require participants to read underpinned the decision to 
Table 1

The Sustainable Tourism Concourse, relevant to the tourism experiences offered in the Tarkine and Tasmanian context.

\begin{tabular}{|c|c|c|c|c|}
\hline & & \multicolumn{3}{|c|}{ Type of Sustainable Tourism Development } \\
\hline & & Niche Sustainable Tourism & Moderate Sustainable Tourism & Mass Sustainable Tourism \\
\hline Defining Attributes & Sub Attributes & Descriptors & & \\
\hline \multirow[t]{2}{*}{ 1. Access } & Difficulty of Access & $\begin{array}{l}\text { Challenging access that requires } \\
\text { logistics and planning }\end{array}$ & $\begin{array}{l}\text { Moderate accessibility that } \\
\text { requires a level of planning }\end{array}$ & $\begin{array}{l}\text { Easy access with little planning } \\
\text { required }\end{array}$ \\
\hline & Type of Transport & Trails and specialist aircraft & $\begin{array}{l}\text { Vehicles for Gravel and Paved } \\
\text { roads }\end{array}$ & Large capacity transport \\
\hline 2. Accommodation & Size of Accommodation & $\begin{array}{l}\text { No accommodation- visitors must } \\
\text { carry in tents }\end{array}$ & $\begin{array}{l}\text { Low-Moderate level of } \\
\text { development }\end{array}$ & $\begin{array}{l}\text { Moderate to resort style } \\
\text { development }\end{array}$ \\
\hline \multirow[t]{2}{*}{ 3. Management } & Infrastructure \& Facilities & $\begin{array}{l}\text { None, or very little facilities and } \\
\text { infrastructure }\end{array}$ & $\begin{array}{l}\text { Moderate level of facilities and } \\
\text { infrastructure }\end{array}$ & $\begin{array}{l}\text { High level of facilities and } \\
\text { infrastructure }\end{array}$ \\
\hline & Crowding & $\begin{array}{l}\text { Very little contact, travel in small } \\
\text { groups }\end{array}$ & $\begin{array}{l}\text { Some contact, travel in medium } \\
\text { sized groups }\end{array}$ & Frequent contact, large groups \\
\hline \multirow[t]{2}{*}{ 4. Visitor Experiences } & Modifications to the Environment & $\begin{array}{l}\text { Low-little modification to natural } \\
\text { environment }\end{array}$ & $\begin{array}{l}\text { Moderate - some modifications to } \\
\text { natural environment }\end{array}$ & $\begin{array}{l}\text { High - significant modifications to } \\
\text { natural environment }\end{array}$ \\
\hline & Group activity & Highly immersive & Facilitated nature activity & Low immersion \\
\hline
\end{tabular}

choose a pictorial method. In addition to the advantage of being appropriate for illiterate populations, visual depictions such as photographs can increase response validity (Manning \& Freimund, 2004). Photographs act as 'surrogates' for reality (Jacobsen, 2007) and have additional advantages: they standardise the 'question' in that each visitor sees exactly the same picture, compared to narratives where the respondent might need to 'fill in the gaps' or make assumptions; they allow a very clear focus on selected variables (e.g. crowding), keeping other factors constant; they may depict a situation more clearly than a narrative description; they are an economically viable research technique (Jacobsen, 2007); and they can be edited to depict situations that do not currently exist such as a possible future scenarios (Manning \& Freimund, 2004). Some areas of concern in using visual images have also been highlighted as including the image quality (e.g. high resolution), type (e.g. cartoon, photo shop, natural) and ensuring that the depiction of content is 'like' the respondents (specifically in relation to people (Manning \& Freimund, 2004). There are also suggestions that aspects such as weather must remain consistent in all photographs- thus the need for standardised background conditions (Jacobsen, 2007).

Pictorial techniques are not commonly used in tourism research, but one that has been identified as useful for tourism research is the $\mathrm{Q}$ methodology (Stergiou \& Airey, 2011). The Q methodology evolved from factor analysis theory and requires participants to express their views on issues through photographs or statements. These photographs are then subjected to statistical factor analysis. It is the ability to decipher the 'significance to me' or individual's subjectivity, which sets Q methodology apart from positivist inquiry (Stergiou \& Airey, 2011). Originally developed in landscape research, Q methodology was first documented by Stephenson in 1935 and since then has been used over 2500 times according to Byrd et al. (2009). It is rarely used in tourism research. Exceptions to this include Dewar, Li, and Davis (2007), Fairweather and Swaffield (2002) and Jurowski and Dogan (2004). Q methodology was ideal for this research as it had the capacity to elicit insights from the perspective of participants and did not impose a priori meanings. It required no level of literacy and its lack of use in tourism and the Tarkine region, meant it was a novel approach that the research team hoped would interest participants.

On a functional level, $\mathrm{Q}$ methodology has been determined to involve five steps (Stergiou \& Airey, 2011; Hunter, 2013):

1. Generate the concourse and $\mathrm{Q}$ set. This involves identifying the social discourse and extracting representative photographs that depict the range of issues for sustainable tourism development in the region under study;

2. Recruit the $\mathrm{P}$ set. This involves the use of purpose sampling techniques to find respondents from stakeholder groups that are involved in, or are affected by the social discourse;

3. Perform the Q sort. Respondents are interviewed and asked to sort photographs mounted on cards into piles ranging in a distribution from strongly like to strongly dislike and the sorted distributions are recorded;

4. Process Q sorts using mathematical (PQMethod program) and interpretive analysis; and

5. Deliver findings and describe implications.

The application of these five steps to this project was as follows:

Step One- Generate the Concourse and Q Sort: The first step of the $Q$ methodology involved the development of a concourse that would provide the structure and rationale for the choice of photographs respondents would be required to sort. Concourses are researchergenerated representations of the range of potential issues under exploration. They can be developed from interviews or developed from other sources such as existing scales or literature reviews (Stergiou \& Airey, 2011). Given this study's interest in understanding stakeholders' attitudes towards sustainable tourism development, a spectrum of possible tourism options were required for the concourse that would be informed by theory, yet relevant to the study region (Table 1). Within tourism literature a range of spectrums of tourism development have been conceptualised. However not all were relevant to Tasmania and particularly the Tarkine Region, as the case study region was largely made up of small scale, nature-based tourism businesses. It would have been inappropriate to develop a concourse based upon spectrums of tourism development that included urban or mass tourism. Therefore the research team chose Boyd and Butler (1996) Ecotourism Spectrum (ECOS), derived from Clark and Stankey (1979) visitor experience (Recreation Opportunity Spectrum) framework. This spectrum conceptualises a range of tourism development options and had strong synergies with realistic opportunities that could occur (given the geo-political status and nature of tourism) within the case study region.

The research team then adjusted the ECOS spectrum so that it was relevant for a variety of sustainable tourism options (previously it was designed for ecotourism) (Table 1). Following this, in order to ensure its relevance for Tasmania and the Tarkine region, several dimensions were added, such as accommodation and use of energy. The research team chose not to include some ECOS dimensions, such as explorations of style of interpretation, given the goal was to investigate attitudes towards sustainable tourism development (as opposed to ecotourism whose core tenant is interpretation), whose product does not always offer interpretation. Other aspects of the ECOS scale were removed including information channels and marketing, given our focus on 


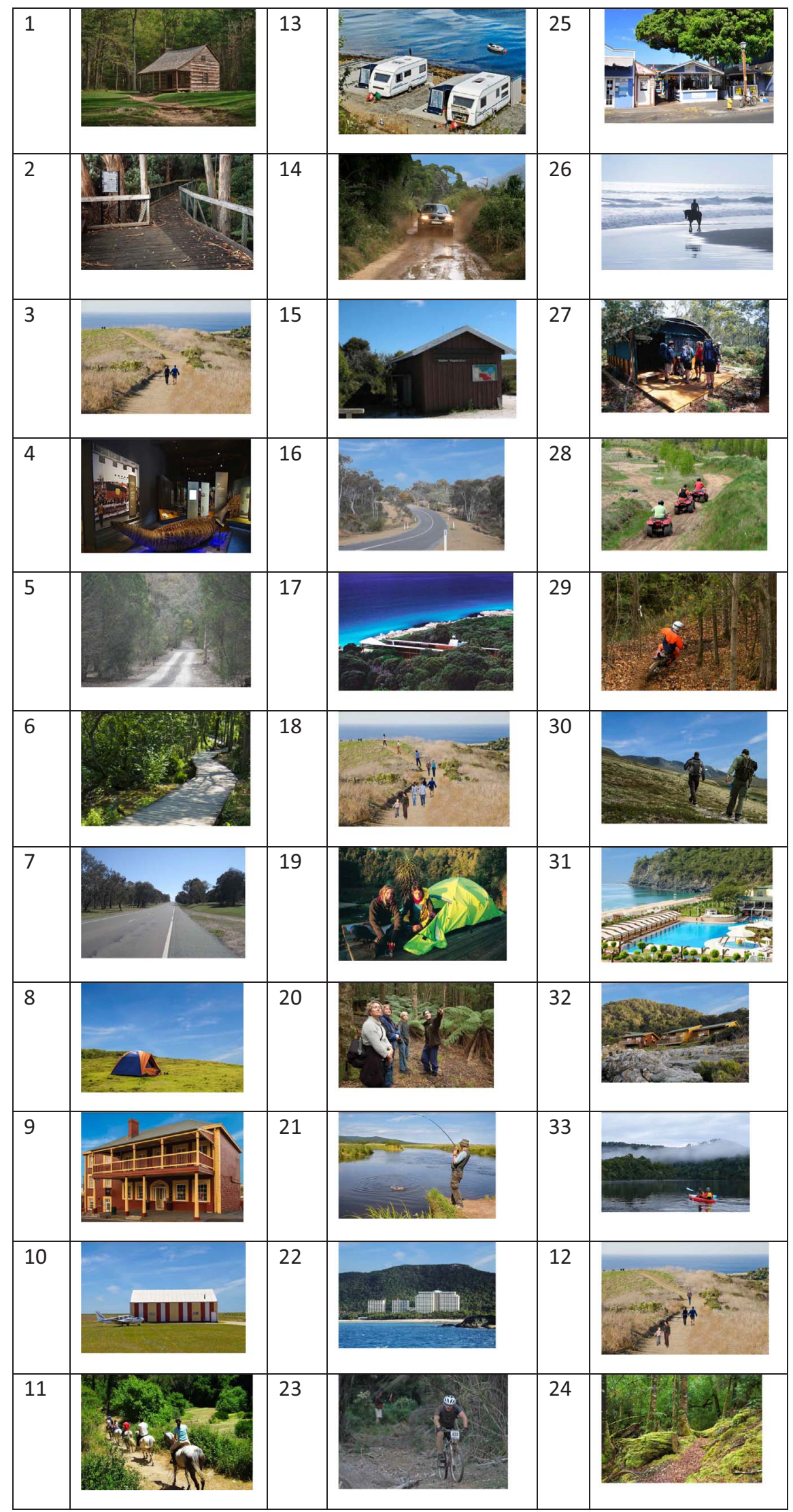

Fig. 1. Photographs used for the Q Sort. 
sustainable product development for the region, rather than attributes related to marketing.

Ultimately, the final concourse represented a range of plausible options for different styles of sustainable tourism development in the Tarkine region, informed by a pre-existing spectrum for tourism development (Table 1). Four defining attributes for sustainable tourism development were present within the concourse: access; accommodation; management; and visitor experiences.

The Q set (range of photographs used to depict the concourse) comprised of 32 photographs (Fig. 1). Given the undeveloped nature of tourism in the Tarkine, the research team deemed it appropriate to have three photographs for each of the accommodation descriptors. This allowed stakeholders in the case study regions to be very specific about the style of accommodation they preferred. For example, within the strong descriptors, the research team chose a photograph of a lone tent in the wilderness; a tent that was set on a hardened campsite; and a 'glamping' style tent that was clearly semi-permanent (Fig. 1). The number and spread of photos was within conventional expectations and acceptability for small-sample Q-studies (see Rogers, 1995). The final set of images was selected from a variety of sources, including shutterstock, the team's own private photograph collection and photos from the Tourism Tasmania photographic library. Copyright permission was gained for all photographs used in the research. Some digital changes to photographs were made, to ensure consistent weather conditions and quality. Three rounds of piloting occurred, with some changes to the photograph composition and style occurring after this process. During the pilot stage, five pilot participants described what the photographs represented to them. This assisted the research team in selecting photographs that corresponded with the concourse. The research team also consulted a key member of the Tasmanian tourism industry to assist in the selection of photographs that were appropriate for the style of tourism currently available in the region, and for styles of tourism that would be possible in the near future in the Tarkine region. After selection of the final photographs each of the photographs were assigned random numbers for data- recording process (Stergiou \& Airey, 2011).

Step Two-Recruit the P Set: The second step was to identify and recruit the $\mathrm{P}$ set. This step required identifying our stakeholder groups, based on the historical discourse. The team utilised a purposive sampling strategy as theory-driven and context-specific approach appropriate for understanding a wide variety of attitudes (Hunter, 2013). The $P$ set consisted of 38 respondents from four tourism stakeholder groups: operators (8 respondents), regulators (5 respondents), community group members (five respondents from local advocacy groups) and locals (21 respondents). This number was appropriate for Q-studies whose emphasis is on individual subjectivity, meaning a small number of participants is appropriate (Valenta \& Wigger, 1997) and is consistent with previous studies using $\mathrm{P}$ sets of 34 (Hunter, 2013), 30 (Brown, 1980), 27 (Dewar et al., 2007) and 30 (Hunter, 2011). There were challenges in selecting the locations to conduct the interviews with 'locals' as there are many towns within the Tarkine region. As such, the research team opted to split data collection between Smithton, a large agricultural hub for the region, and Wynyard a service centre and tourism hub.

Step Three- Undertake Q Sort: The third step involved 38 respondents conducting a $\mathrm{Q}$ sort. Each participant was asked to arrange the 32 photographs into three piles (most preferred, least preferred, unsure/ undecided) and then across the distribution of 9 columns (Brown, 1980; Fairweather \& Swaffield, 2001). The Q sort interview was audio recorded and interviews conducted between November 2013 and March 2014.

Step Four-Analysis: This was completed with the software program PQMethod, Version 2.33 (Schmolk, 2009) and focused on investigating the correlation between each subject's $Q$ sort and every other participant's Q sort. A principal components analysis was conducted on the correlation matrix in order to generate factors or groups of participants that sorted the photographs in a similar way. The initial output was a listing of all participants with a nominal loading, or association with as many factors as were appropriate for the data. In this first output, analysis revealed that most of the participants were loaded on the first factor. These data were then modified by varimax rotation to determine the simplest structure in the data. This process spread the variance across the factors in order to get more participants loading on factors other than factor 1 . The result was identification and a count of significant loaders on each factor. Following Brown (1980), the team included factors that had at least two significant loaders on the unrotated factor matrix. The significance level was derived from the standard error formula of $1 / \mathrm{VN}$, where $\mathrm{N}$ equals the number of items in the $\mathrm{Q}$ method. For this study, the derived value for 32 items was 0.17 , and at the 0.01 level of confidence this value was multiplied to 2.58 to set the significant level at 0.45 . Loadings had to be 0.45 or above to be judged as significant. In addition traditional scree plots were used to determine where factor cut-offs should be determined to ensure a minimum sufficient set of factors that represented the data (see Fairweather, 2002 for further explanation). The analysis produced three factors that accounted for 32 of the 38 sorts, with levels of significance ranging from 0.87 to 0.40 . 6 sorts were statistically significant in more than one factor, or confounded and excluded. The 32 sorts, three factors and scores and stakeholder groups, eigenvalues and explained variance are presented in Table 1.

Subsequently, analysis focused on the core factors and those participants loading heavily onto each factor, developing a rich set of information about each factor. Participants who loaded strongly on a factor had a proportionately greater influence on the factor's characteristics. The team could then identify which images were highly negatively or positively significant for each factor as well as which images and people exemplified each factor. As with any factor analysis, not every person would load on the identified factors. The results are described in the following section.

In addition to the quantitative analysis, participant's responses were recorded and transcribed. This enabled the research team to understand their rationale for the position that they sorted each photograph. This data was analysed manually, by matching the comments with the photographs and then comparing individuals reactions to each of the photographs 'and their reasoning for their positioning of each photograph. Therefore, the qualitative analysis 'fleshed out' participants reasons for their $\mathrm{Q}$ sorts. The analysis then proceeded, with the following steps: Identification of participants and their corresponding traditional stakeholder group within each factor; Analysis of their attitude towards the region; Analysis of their attitude towards tourism in the region; and Analysis of their comments towards the statistically significant photographs.

Step Five- Development of Findings and Implications: It was during this explanatory stage that the research team named the factors with descriptors that matched the predominant attitudes of the factors and assessed the implications for theory on attitudinal alignment of stakeholder groups, sustainable tourism development and practice in the Tarkine.

\section{Results}

The data analyses identified three factors of attitudes towards sustainable tourism development. These factors are based on four characteristics. First, they included consensus images, whereby all respondents in the Tarkine agreed with a significance rating of $\mathrm{P}>0.05$ (entire P set). The second was that they included distinguishing images for each factor where all respondents within the factor agreed. The third characteristic of the factors was that each picture was given a distinguishing score, to identify its relative importance to each factors. Finally the factors contained qualitative defining statements gained through interview transcripts and thematic analysis, for each factor. 
Table 2

Q-sort factor analysis results. 32 Q sorts accounted for in 3 factors out of $8 ; 6$ sorts significant in two or more factors (confounded).

\begin{tabular}{|c|c|c|c|c|}
\hline Sort & Respondents $^{\mathrm{a}}$ & A (18) & B (6) & $C(8)$ \\
\hline 22 & Op 18 & 0.8741 & & \\
\hline 16 & Loc 88 & 0.7577 & & \\
\hline 37 & Comm 19 & 0.7515 & & \\
\hline 7 & Loc 7 & 0.7351 & & \\
\hline 17 & Loc 89 & 0.7308 & & \\
\hline 8 & Loc 8 & 0.7107 & & \\
\hline 25 & Op38 & 0.6832 & & \\
\hline 5 & Loc 5 & 0.6662 & & \\
\hline 29 & Op 34 & 0.6520 & & \\
\hline 4 & Loc 4 & 0.6277 & & \\
\hline 1 & Loc 1 & 0.6270 & & \\
\hline 33 & Reg 35 & 0.6242 & & \\
\hline 31 & Reg 16 & 0.6055 & & \\
\hline 15 & Loc 87 & 0.5971 & & \\
\hline 13 & Loc 85 & 0.5779 & & \\
\hline 19 & Loc 91 & 0.5744 & & \\
\hline 12 & Loc 12 & 0.5055 & & \\
\hline 23 & Op17 & 0.4085 & & \\
\hline 27 & Op37 & & 0.8582 & \\
\hline 3 & Loc 3 & & 0.7858 & \\
\hline 10 & Loc 10 & & 0.7805 & \\
\hline 35 & Comm 97 & & 0.7429 & \\
\hline 6 & Loc 6 & & 0.6579 & \\
\hline 36 & Comm 20 & & 0.6018 & \\
\hline 34 & Reg 33 & & & 0.7910 \\
\hline 28 & Op36 & & & 0.7645 \\
\hline 32 & Reg 21 & & & 0.6495 \\
\hline 24 & Op 14 & & & 0.6457 \\
\hline 14 & Loc86 & & & 0.6187 \\
\hline 2 & Loc 2 & & & 0.6108 \\
\hline 21 & Loc 93 & & & 0.5995 \\
\hline 38 & Comm 15 & & & 0.4798 \\
\hline
\end{tabular}

Sorts $9,11,18,20,26$, and 30 confounded

Eigen-values and explained variance between un-rotated factors:

\begin{tabular}{lllllllll}
\hline 8 Factors & A & B & C & D & E & F & G \\
$\begin{array}{l}\text { Totals } \\
\begin{array}{l}30.83 \\
\text { \% variance }\end{array}\end{array}$ & Eigen-value & 16.87 & 4.06 & 2.34 & 1.87 & 1.65 & 1.52 & 1.38 \\
\hline
\end{tabular}

The three factors that emerged from the analysis were:

${ }^{\text {a }}$ Respondents key: Loc $=$ locals, Reg $=$ regulator, Comm $=$ community group

For the Tarkine region there were four consensus images that every respondent agreed upon, as well as a distinct indifference to a photograph of a gravel road and a marginal dislike for outback roads with gravel edges. There was a unified dislike for the photograph of a huddle of several shops, and a light airplane strip and hangar (Table 2).

\subsection{Tarkine factor A: Protectionists}

Protectionists were defined by images that reflect the largest relative difference in subjectivities between factors as identified with rank scores $(-4,-3,3,4)$ in each factor. This factor had a high preference for underdeveloped low activity tourism development (Table 3) and was made up of primarily locals, along with community groups members, those in regulatory positions and operators (Table 6).

When asked what word best describes the Tarkine, Protectionists described it as a diverse landscape, valued for many reasons for its uniqueness, wildness, challenging nature, pristine-ness, ancient landscape and cultural importance. They also described it as vulnerable, endangered, and misunderstood. Protectionists predominantly felt the Tarkine needs protection. Yet despite their name they supported tourism in the Tarkine. Some saw it as the saviour for the Tarkine, while others saw it as too fraught with difficulties to be a potential saviour (although still worthwhile). The defining photograph that characterised Protectionists' attitudes was that of the undeveloped tracks (see Table 3). Protectionists indicated their desire for tourism activity in the Tarkine but with a strong preference for tourism experiences to allow for immersive nature based experiences, with infrastructure that facilitated visitation with minimal impact. They had a strong desire for controls of impact and numbers. They also felt that tourism should be accessible to all - elderly, disabled, and not only for people with high incomes.

Almost all Protectionists were willing to see more tourists in the region but wanted to ensure that tourism was developed sustainably.

[Member of Community Group \#19] '...I think it should certainly be attracting more [tourists]. The infrastructure work to make that happen is really important but it's an area until the last decade that really hasn't had a high level of visitation and it's growing and there's business developing.'

Suggestions included a need for more infrastructure, a stronger brand and identity for the Tarkine, tourism that capitalised on the cultural and natural assets of the region and a more even spread of 
Table 3

Protectionists (Factor A), with statistically significant distinguishing statements $(\mathrm{P}<0.01)$.

\begin{tabular}{lll}
\hline Image no. & Description & Rank \\
\hline 24 & Undeveloped track & 4 \\
6 & Hardened track no edges & 3 \\
31 & Extensive resort with pool & -2 \\
14 & Motorised vehicles & -2 \\
29 & Motorbike - lone & -3 \\
28 & Several quad bikes & -3
\end{tabular}

visitation across the seasons.

[Regulator \#16]'...more tourists, we could easily attract more tourists. At the moment there is a bit of an identity crisis, not really sure what to promote in the community.'

Analysis of this factor also revealed the forms of tourism that Protectionists disliked. 'Disliked' photographs included: a photograph of a lone motorbike; a group of quad bikes; and a motorised vehicle. They were seen as inappropriate because they are environmentally destructive; would impede on other activities; were hard or impossible to manage; and focused on the thrill of the activity rather than care or respect the environment. It should be noted that a small number of Protectionists supported these activities as long as they were conducted on private land or land set aside for that use only.

\subsection{Tarkine factor B: Multi-users}

Multi-users' defining feature was that it had no stakeholders from the regulator group (see Table 4). It was a multi-stakeholder group made of locals, community group representatives and operators. This factor described the Tarkine as unique, picturesque and marvellous. However, they also recognised that the region has many uses and a history of 150 years of activities such as logging and mining. One person mentioned that it is a potential 'fire ball' and was not being managed properly. Multi-users were a coherent group in terms of their preferred tourism activities. The defining photographs that charac-

Table 4

Multi-Users' (Factor B) statistically significant distinguishing statements ( $\mathrm{P}>0.01$ ).

\begin{tabular}{lll}
\hline Image no. & Description & Rank \\
\hline 26 & Lone horse riding & 4 \\
28 & Several quad bikes & 3 \\
14 & Motorised vehicles & 3 \\
15 & Lone shed in National Park & -2 \\
4 & Indigenous Tourism canoe & -2 \\
17 & Eco-lodge & -2 \\
\hline
\end{tabular}

terised and bound this group together stood in stark contrast to Protectionists. The photographs that Multi-users 'liked' included: the lone horse rider; a group of quad bikes; and a photograph of the motorised vehicle (Table 4). This is reinforced by the distinguishing

Table 5

Rugged Pragmatists (Factor C) statistically significant distinguishing statements $(\mathrm{P}>0.01)$.

\begin{tabular}{lll}
\hline image no. & Description & Rank \\
\hline 33 & Kyaking alone & 4 \\
8 & Lone tent & 3 \\
32 & Many cabins & 2 \\
7 & Road with green edges & -2 \\
18 & Frequent interparty contacts & -2 \\
22 & Several resorts & -4 \\
\hline
\end{tabular}

characteristics of the factor.

To many Multi-users, their selection of activity reflected an activity of their own personal preference. These activities were seen as good ways to access much of what the Tarkine has to offer, and experience the bush, landscapes and beaches. Moreover, the forms of motorised transport were also seen as able to provide access for the elderly, people with a disability or family groups.

[Member of Community Group \#20]'...exploring and getting around, as you get older can't walk around as much and need to have the freedom of being self-sufficient.'

Others indicated that a system of education and permits would be necessary to ensure minimal damage.

[Member of a Community Group \# 97]'...the challenge of doing the riding: it's riding through the environment and you gain access to the best beaches in the world. Sandy Cape beach, Arthur River beach... Small groups with registration and permits and everything else like that. ... when they buy their permits they've gone through a registration process to say that I've looked at this DVD, I understand the importance of staying on the track, I understand that I've got to be licenced for MIAB, I understand that I am not allowed to destroy the area.'

Members of this factor had two views on tourism, although both groups had overriding concerns about access and control in the region. The first view was that tourism was unlikely to be viable in the region, because the existing tourism opportunities were limited unless visitors were able to access the coast. The other group of Multi-users saw tourism in a more positive light, believing it allowed for the isolation and landscape to be experienced. They did however, recognise that tourism was hampered by a lack of development, especially roads and access to the area, meaning that it is currently only accessible to people who can hike to access it.

There were also divisions in this group over the impacts of tourism development: this became evident when explaining why they preferred more, less or the same tourism development. Some wanted more tourism, but only if infrastructure was provided. They were clearly resentful towards environmental conservation groups who they felt did not want development:

[Local \#3]'The problem arises when/if the Tarkine is opened up so the Greens can close it down. People don't really understand it all. Forestry has suffered and there is a public misconception of how the Tarkine is being managed.

Other Multi-Users wanted the same level of tourism in order to protect the sense of remoteness:

[Member of a Community Group \# 20]'... about the same. We (four-wheel driving club) don't want more there. The attraction is the freedom and being away from highly populated areas.'

And a third group of Multi-users wanted fewer tourists in the region and felt the region was largely misunderstood:

[Local\#6]'...fewer, don't think it can be a major tourism attraction. There is capacity to increase tourism numbers if managed properly. The government doesn't understand the region.'

The photographs that multi-users disliked included an eco-lodge and a bushwalking registration booth because they felt they were not needed in the Tarkine; and because Multi-users felt the Tarkine should establish itself as different to well-known Tasmanian destinations such as Cradle Mountain.

\subsection{Tarkine factor C: Rugged pragmatists}

The Rugged Pragmatists factor had stakeholders from each of the stakeholder groups within it (Table 5). Rugged pragmatists described 
Table 6

Count of stakeholders categories in each Tarkine factor.

\begin{tabular}{llll}
\hline & Protectionists (A) & Multi-Users (B) & Rugged Pragmatists (C) \\
\hline Operators & 4 & 1 & 2 \\
Regulators & 2 & 0 & 2 \\
Community & 1 & 2 & 1 \\
Locals & 11 & 3 & 3 \\
Total & $\mathbf{1 8}$ & $\mathbf{6}$ & $\mathbf{8}$ \\
\hline
\end{tabular}

the Tarkine as a place where the landscape and biodiversity is extremely diverse, resulting in it being a very beautiful and rugged location. They recognised that it was subject to controversy regarding its name, its values, and its use. Significantly, when describing the area, this factor did not mention the word 'pristine'. This identity was reinforced by the distinguishing images for this factor displayed in Table 5 which emphasizes solitary activities.

The photographs that characterised this group included a kayak, a lone tent in the wilderness and a group of cabins. Analysis revealed concern over the need for more tourism opportunities for visitors including activities they can do, and a range of accommodation options. Stakeholders within this group also expressed a desire for tourism activities to 'fit in' with the Tarkine:

[Regulator \#21]'... there's some fantastic waterways, potential around kayak tourism opportunity, camping and that sort of thing, it gets to the essence about what I think people think the Tarkine is.'

They also expressed a desire for activities and accommodation to be low in environmental impact activities and to cater for the free independent traveller. They wanted people to experience the environment and develop an appreciation for it.

[Operator \#36] '...it represents a range of what people can do there independently, which is good and should always allow people to do this...having something that is accessible for people who wouldn't do it this way is really important because you get people to go down there and experience it...something for everybody.'

Rugged Pragmatists felt that the region had great potential to grow and that more resources were needed in order to manage the impact of tourism, particularly to ensure tourism is environmentally sustainable. They believed that the region in its current state was undeveloped and constrained in its capacity to accommodate only a small number visitors in a limited area, meaning tourists 'only get at the edges of it'. As such it was significant that Rugged Pragmatists differed from the other factors, in that all stakeholder groups agreed that more tourists were needed in the Tarkine.

[Operator \#36]'... I want more tourists but there needs to be possibly more infrastructure... small amount of infrastructure but probably planned out a little bit better for them, as far as things to do...stop people from going too far off track...'

[Regulator \#33]'... Catch twenty-two because if it has infrastructure it could attract more tourists but where do they go? Corinna has capacity. Tarkine has good values therefore needs more visitors with more scope for more experiences. As a remote part of NW it struggle for jobs.'

Table 7

Correlation of factors with respect to their composition of stakeholder groups.

\begin{tabular}{llll} 
& Factor $A$ & Factor B & Factor C \\
\hline Factor A & 1 & & \\
Factor B & 0.682048 & 1 & 1 \\
Factor C & 0.905357 & 0.5 & 1 \\
\hline
\end{tabular}

Analysis of this factor also revealed the photographs that Rugged Pragmatists disliked, including a photograph of several resorts; a road that was highly developed; and a photograph of many people walking. Rugged Pragmatists did not like these forms of tourism development because they felt the accommodation did not suit the area, and did not match the character of the Tarkine. They also suggested that the road looked out of place and there was concern that it would result in high volume, faster traffic and associated impacts such as road kill and rubbish. They felt that roads, such as the one in the photograph should only be in limited places. The track with many people on it was disliked because it did not encourage interaction with the environment and was seen as aesthetically unattractive. Overall, it appeared that stakeholders in this factor were concerned about the current forms of infrastructure and volume of visitors. Their attitude was that the Tarkine should allow access and increased visitors, but in a small and controlled manner.

\subsection{Alignment of stakeholder groups to factors}

The focus of this research was to assess the alignment of individual stakeholders' attitudes with their traditionally defined stakeholder groups, with respect to sustainable tourism development. The factor analysis revealed that three attitudinal groups emerged among the four groups of stakeholders that participated in this research: Protectionists, Multi-users and Rugged Pragmatists. These groups were homogenous with clear preferences and dislikes for tourism development. For example, Protectionists were an easily definable groups through their preference photograph that represented niche forms of sustainable tourism (Table 1). They preferred low-key development, low levels of visitation, undeveloped landscapes and spoke of the Tarkine's unique, natural and endangered qualities. Protectionists included individuals from all stakeholder groups, although higher number of operators (4/7) and locals (11/17) were present in this attitudinal group. Multi- users were made up of locals; a smaller number if operators (1/11) and had no regulators in their group. This attitudinal group was aware of the Tarkine's diverse history of industries, was concerned about the protection of their own recreational spaces and supported an increase in diverse tourism experiences. The third group, Rugged Pragmatists, included almost equal numbers of operators, regulators, those in community groups and locals. They had a desire for an increase in tourism infrastructure but only if done so in a sensitive manner.

Importantly for this paper, each factor had individuals from a variety of the traditional stakeholder groups (Table 6).

In order to determine whether there was any relationship between traditional stakeholder groups and factors, we investigated if the factors were correlated with respect to their traditional stakeholder groups. The correlation coefficient (a value between -1 and +1 ) illustrates the strength between two variables and the analysis identified that the three factors were highly correlated (Table 7).

This indicates that the individuals from the four traditional stakeholder groups (as identified in literature and historical analysis) were present throughout the three factors. Thus it suggested that individual stakeholders' attitudes did not correlate with traditional stakeholder groups in relation to attitudes towards sustainable tourism development.

\section{Discussion}

This study has contributed to the existing body of theory on stakeholder theory by exploring whether individual stakeholders' attitudes aligned with their traditional stakeholder groups, in relation to attitudes towards sustainable tourism development. This research used the Q methodology to tackle this issue and in doing so, supports the work of recent work (see Beritelli, Buffa, \& Martini, 2016; Hunter, 2013) that challenges the notion that stakeholders' attitudes are specific to their group. It demonstrates that the traditional stakeholder groups of operators, locals people, those in regulatory positions and members 
of community groups are not always homogenous in their attitudes. Some alignment was apparent within the Protectionists group who contained the highest proportion of locals and operators. However, the appearance of both traditional stakeholder groups within the same attitudinal group represents a departure from the traditional thinking that two stakeholder groups such as locals and operators have differing attitudes. The remaining two attitudinal groups (Multi-users and Rugged Pragmatists) also contained a cross section of stakeholders, further supporting the suggestion that attitudinal groups may be a more appropriate means to decipher homogeneity in stakeholder attitudes.

This research also challenges the assumption often made by planners that operators are supportive of development or that regulators are risk averse and wary of further tourism development. In the case of this research, the 'Protectionist' attitudinal group, (consisting of individuals with a concern about sustainability and a desire for very low-key, niche styles of sustainable tourism) contained the highest proportion of operators.

The contextual opinions that were evident among the stakeholders also suggested that attitudes towards sustainable tourism development might vary between regions and depending upon the socio-political context of the region under study. The implications of these findings are that stakeholder research must be an ongoing process, as well as contextual, in order to ensure that decision making related to tourism is as responsive and reflexive as possible.

The decision to assess multiple stakeholder groups concurrently was made following observations of the tendency of tourism research to assess one stakeholder group at a time. Given recent global contractions in the research-funding environment, his trend is likely to be increasingly common. The single approach should not be entirely discounted; there have been significant advances made in terms of issues such as community attitudes towards tourism (Lepp, 2007; Liu \& Var, 1986), the impacts that distance and involvement in the industry has upon residents attitudes (Jurowski \& Dogan, 2004), tourists' attitudes towards the environment (Dolnicar, Crouch, \& Long, 2008) and the relationship between tourism and residents 'sense of place' (Derrett, 2003). However, single stakeholder studies run the risk of perpetuating an assumption that attitudes are specific to stakeholder group. Indeed the stakeholder literature has helped enforce this assumption by discussing the existence of stakeholder group specificity (Byrd et al., 2009; Timur \& Getz, 2009). The attitude factors that cross stakeholder groups that have been revealed in this research are particularly relevant given that there are numerous researchers advocating for multiple stakeholder research as a means to ensure that sustainable tourism goals are met (Hardy \& Beeton, 2001; McCool et al., 2001).

Methodologically, this research is highly significant given the 'critical turn' recently documented within sustainable tourism literature (Bramwell and Lane, 2014). The Q methodology has rarely been applied in tourism research (exceptions include Fairweather \& Swaffield, 2001, 2002, 2003; Hunter, 2011, 2013, 2014; Stergiou \& Airey, 2011; Phi et al., 2014). In the case of this research, where literacy rates were low and over-research was a significant hurdle for researchers, the pictorial method was attractive to participants and accessible to individuals who previously may not have been able to complete written questionnaires. Respondents reactions to this research was similar to that reported by Hunter (2013); they became highly involved in the process of photograph sorting and often expressed that the photographs prompted them to think of issues in more detail and clarify their position in relation to certain tourism issues. Moreover, the photographs acted as a catalyst to connect more deeply with the participants who were being researched and to understand their perspectives, particularly those who have been traditionally underrepresented by research as a result of their illiteracy. Therefore, the pictorial approach played an important role in facilitating social justice through research, which remains a goal for critical tourism research (Salazar, 2012).

This study supports the argument by authors such as Waligo et al.
(2013) that as long as sustainable tourism remains contentious and there are differences in stakeholder interests, management intervention and the monitoring of stakeholders' attitudes is necessary. However, this research also revealed limitations with the assessment of stakeholder attitudes. From an industry perspective, the normative approach is costly, time consuming and difficult to implement (Hardy et al., 2013). The continued design and application of innovative, relevant and responsive research approaches will play an important role in broadening our understandings of stakeholder attitudes. Further research should assess the application of the Q methodology in tourism related stakeholder research in different cultures. There is also a need for research that compares the opinions of tourists with stakeholders such as regulators, locals and member of community groups; indeed this was a limitation with this piece of research. Findings such as these will continue to challenge our understandings of the commonalities and divergences, which exist among stakeholders.

\section{References}

Andriotis, K. (2005). Community groups' perceptions of and preferences for tourism development: Evidence from Crete. Journal of Hospitality and Tourism Research, 29, 67-90.

Australian Bureau of Statistics (2013). Adult literacy and life skills survey 2011-2012. Canberra: Australian Bureau of Statistics.

Ballanyne, R., Packer, J., \& Falk, J. (2011). Visitors' learning for environmental sustainability: Testing short- and long-term impacts of wildlife tourism experiences using structural equation modelling. Tourism Management, 32, 1243-1252. http://dx. doi.org/10.1016/j.tourman.2010.11.003.

Becken, S. (2003). Operators' perceptions of energy use and actual saving opportunities for tourism accommodation. Asia Pacific Journal of Tourism Research, 18, 72-91. http://dx.doi.org/10.1080/10941665.2012.688512.

Beritelli, P., Buffa, F., \& Martini, U. (2016). Logics and interlocking directorships in a multi-stakeholder system. Journal of Destination Marketing and Management, 5, $107-116$.

Bohm, D. (1990). On dialogue. Cambridge: Pegasus Communications.

Bornhorst, T., Ritchie, J. R., \& Sheehan, L. (2010). Determinants of tourism success for DMO's and destinations: An empirical examination of stakeholders' perspectives. Tourism Management, 31, 572-589. http://dx.doi.org/10.1016/j.tourman.2009.06. 008.

Boyd, S., \& Butler, R. (1996). Managing ecotourism: An opportunity spectrum approach. Tourism Management, 17, 557-566. http://dx.doi.org/10.1016/S0261-5177(96) 00076-3.

Brawmell, B., \& Lane, B. (2014). The 'critical turn' and its implications for sustainable tourism research. Journal of Sustainable Tourism, 22, 1-8.

Bramwell, B., \& Sharman, A. (1999). Collaboration in local tourism policymaking. Annals of Tourism Research, 26(2), 392-415. http://dx.doi.org/10.1016/S0160-7383(98) 00105-4.

Brookfield, S. (2005). The power of critical theory for adult learning and teaching. Berkshire: Open University Press.

Brown, S. (1980). Political subjectivity: Applications of Q method in political science. New Haven, CT: Yale University Press.

Byrd, E. (2007). Stakeholders in sustainable tourism development and their role in sustainable tourism development. Tourism Review, 62, 6-13. http://dx.doi.org/10. 1108/16605370780000309.

Byrd, E., Bosley, H., \& Dronberger, M. (2009). Comparisons of stakeholder perceptions of tourism impacts in rural eastern North Carolina. Tourism Management, 30, 693-793. http://dx.doi.org/10.1016/j.tourman.2008.10.021.

Byrd, E., \& Gutske, L. (2007). Using decision trees to identify tourism stakeholders: The case of two Eastern North Carolina counties. Tourism and Hospitality Research, 3-4, 176-193. http://dx.doi.org/10.1057/palgrave.thr.6050049.

Chen, J. (2014). Tourism stakeholders attitudes toward sustainable development: A case in the Arctic. Journal of Retailing and Consumer Services, 22, 225-230. http://dx.doi. org/10.1016/j.jretconser.2014.08.003.

Cheng, S., Hu, J., Fox, D., \& Zhang, Y. (2012). Tea tourism development in Xinyang: Stakeholders' view. Tourism Management Perspectives, 2-3, 28-34. http://dx.doi.org/ 10.1016/j.tmp.2011.12.001

Choi, H., \& Sirakaya, E. (2005). Measuring residents' attitude towards sustainable tourism: Development of sustainable tourism attitude scale. Journal of Travel Research, 43, 380-394. http://dx.doi.org/10.1177/0047287505274651.

Clark, R., \& Stankey, G. (1979). The recreation opportunity spectrum: A framework for planning, management and research (Research Paper PNW-98)Portland, OR: Oregon: USDA Forest Service.

Clarkson, M. (1995). A stakeholder framework for analysing and evaluating corporate social performance. Academy of Management Review, 20, 92-117. http://dx.doi.org/ 10.5465/AMR.1995.9503271994.

Corinna (2014). Corinna: At home in the wilderness. 〈http://www.corinna.com.au〉. Accessed 13 May 2014.

Cradle Coast Authority (2008). Tarkine tourism master plan. Burnie: Cradle Coast Authority.

Currie, R., S. Seaton, S., \& Wesley, F. (2009). Determining stakeholders for feasibility 
analysis. Annals of Tourism Research, 36, 41-46.

Department of the Environment, Western Tasmania Aboriginal cultural landscape (2014). 〈http://www.environment.gov.au/topics/heritage〉 Accessed 15 May 2014.

Derrett, R. (2003). Making sense of how festivals demonstrate a community's sense of place. Event Management, 8, 49-58. http://dx.doi.org/10.3727/ 152599503108751694.

Dewar, K., Li, W. M., \& Davis, C. H. (2007). Photographic images, culture, and perception in tourism advertising: A Q methodology study of Canadian and Chinese university students. Journal of Travel \& Tourism Marketing, 22, 35-44. http://dx.doi.org/10. 1300/J073v22n02 03

Dodds, R. (2007). Sustaainble tourism and policy implementation: Lessons from the case of Calvia, Spain. Current Issues in Tourism, 10, 296-322. http://dx.doi.org/10.2167/ cit278.0.

Dolnicar, A., Crouch, G., \& Long, P. (2008). Environment-friendly tourists: What do we really know about them? Journal of Sustainable Tourism, 16(2), 197-210. http://dx doi.org/10.2167/jost738.0.

Donaldson, T., \& Preston, L. E. (1995). The stakeholder theory of the corporation: Concepts, evidence and implications. Academy of Management Review, 20, 65-91. http://dx.doi.org/10.5465/AMR.1995.9503271992.

Driml, S. M. (1996). Sustainable tourism in protected areas? (PhD thesis)Canberra: Australian National University.

Fairweather, J., \& Swaffield, S. (2001). Visitor experiences of Kaikoura, New Zealand: An interpretive study using photographs of landscapes and Q method. Tourism Management, 22, 219-228. http://dx.doi.org/10.1016/S0261-5177(00)00061-3.

Fairweather, J. (2002). Factor stability, number of significant loadings and Interpretation: results from three case studies and suggested guidelines. Operant Subjectivity, 25, 37-58.

Fairweather, J., \& Swaffield, S. (2002). Visitors' and locals' experiences of Rotorua, New Zealand: An interpretative study using photographs of landscapes and Q method. International Journal of Tourism Research, 4, 283-297. http://dx.doi.org/10.1002/jtr. 381.

Fairweather, J., \& Swaffield, S. (2003). Tourist experiences of landscape in New Zealand: Themes from three case studies. Tourism, Culture and Communication, 4, 57-70. http://dx.doi.org/10.3727/109830403108750812.

Freeman, R. E. (1984). Strategic management: A stakeholder approach. Boston, MA: Pitman.

Getz, D., \& Timur, S. (2005). Stakeholder involvement in sustainable tourism: Balancing the voices. In W. Theobald (Ed.), Global tourism (pp. 230-247). (3rd ed.). Oxford: Butterworth Heineman.

Godfrey, K. (1998). Attitudes towards 'sustainable tourism' in the UK: A view from local government. Tourism Management, 19, 213-224. http://dx.doi.org/10.1016/S02615177(98)00020-X.

Grimble, R., \& Wellard, K. (1997). Stakeholder methodologies in natural resource management: A review of principles, contexts, experiences and opportunities. Agricultural Systems, 55, 173-193. http://dx.doi.org/10.1016/S0308-521X(97) 00006-1.

Hall, C. M. (2007). Tourism planning: Policies, processes and relationships. Harlow: Prentice Hall.

Hall, C. M., \& Page, S. J. (1999). The geography of tourism and recreation: Environment, space and place. London: Routledge.

Hardy, A. (2005). Using grounded theory to explore stakeholder perceptions of tourism. Journal of Tourism and Cultural Change, 3, 108-133. http://dx.doi.org/10.1080/ 09669580508668490.

Hardy, A., \& Beeton, R. (2001). Sustainable tourism or maintainable tourism: Managing resources for more than average outcomes. Journal of Sustainable Tourism, 9, 168-192. http://dx.doi.org/10.1080/09669580108667397.

Hardy, A., Beeton, R., \& Pearson, L. (2002). Sustainable tourism: An overview of the concept and its position in relation to conceptualizations of tourism. Journal of Sustainable Tourism, 10, 475-496. http://dx.doi.org/10.1080/09669580208667183.

Hardy, A., Wickham, M., \& Gretzel, U. (2013). Neglected stakeholder groups: The pitfalls of tourism policy development. Journal of Corporate Ownership and Control, 1, 348-359.

Healey, P. (1997). Collaborative planning: Shaping places in fragmented societies. Vancouver: UBC Press.

Hunter, W. C. (2011). Rukai indigenous tourism: Representations, cultural identity and Q method. Tourism Management, 32, 335-348. http://dx.doi.org/10.1016/j.tourman. 2010.03.003.

Hunter, W. C. (2013). Understanding resident subjectivities toward tourism using Q method: Orchid Island, Taiwan. Journal of Sustainable Tourism, 21, 331-354. http:// dx.doi.org/10.1080/09669582.2012.685175.

Hunter, W. C. (2014). Performing culture at indigenous culture parks in Taiwan: Using Q method to identify the performers' subjectivities. Tourism Management, 42, 294-304. http://dx.doi.org/10.1016/j.tourman.2013.12.014.

Jacobsen, J. (2007). Use of landscape perception methods in tourism: A review of photobased research approaches. Tourism Geographies, An International Journal of Tourism Space, Place and Environment, 9, 234-253. http://dx.doi.org/10.1080/ 14616680701422871.

Jamal, T., \& Getz, D. (1999). Community roundtables for tourism-related conflicts: The dialectics of consensus and process structures. Journal of Sustainable Tourism, 7, 290-297. http://dx.doi.org/10.1080/09669589908667341.

Jurowski, C., \& Dogan, T. (2004). Distance effects on residents attitudes towards tourism effects. Annals of Tourism Research, 31, 296-312. http://dx.doi.org/10.1016/j.annals. 2003.12.005.

Kantvilas, G., \& Jarman, S. (1993). The cryptogamic flora of an isolated rainforest fragment in Tasmania. Botanical Journal of the Linnean Society, 111(2), 211-228. http://dx.doi.org/10.1111/j.1095-8339.1993.tb01899.x.

Kuvan, Y., \& Akan, P. (2013). Conflict and agreement in stakeholder attitudes: Residents and hotel managers' views of tourism impacts and forest-related tourism development. Journal of Sustainable Tourism, 20, 571-584. http://dx.doi.org/10. 1080/09669582.2011.617824.

Lee, W., \& Moscardo, G. (2005). Understanding the impact of ecotourism resort experiences on tourists' environmental attitudes and behavioural intentions. Journal of Sustainable Tourism, 13, 546-565. http://dx.doi.org/10.1080/ 09669580508668581.

Legge, R. W. (1928). Tasmanian aboriginal middens of the West Coast. Australian and New Zealand Association for the Advancement of Science, 19, 323-328.

Lepp, A. (2007). Residents' attitudes towards tourism in Bigodi village, Uganda. Annals of Tourism Research, 28, 876-885. http://dx.doi.org/10.1016/j.tourman.2006.03.004.

Liu, J., \& Var, T. (1986). Resident attitudes toward tourism impacts in Hawaii. Annals of Tourism Research, 12, 193-214. http://dx.doi.org/10.1016/0160-7383(86)90037-X.

McCool, S., Moisey, N., \& Nickerson, N. (2001). What should tourism sustain? The disconnect with industry perceptions of useful indicators. Journal of Travel Research, 40, 124-131. http://dx.doi.org/10.1177/004728750104000202.

Manning, R., \& Freimund, W. (2004). Use of visual research methods to measure standards of quality for parks and outdoor recreation. Journal of Leisure Research, 36, 557-579.

Markwick, M. (2000). Golf tourism development, stakeholders, differing discourses and alternative agendas: The case of Malta. Tourism Management, 21, 515-524.

Marshall, N., Marshall, P., Abdullah, A., Rouphael, T., \& Ali (2011). Preparing for climate change: Recognising its early impacts through the perceptions of dive tourists and dive operators in the Egyptian Red Sea. Current Issues in Tourism, 14, 507-518. http:// dx.doi.org/10.1080/13683500.2010.512075.

Miller, G. (2001). The development of indicators for sustainable tourism: Results of a Delphi survey of tourism researchers. Tourism Management, 22, 351-362. http://dx. doi.org/10.1016/S02/S615177(00)00067-4.

Moskwa, E., Higgins-Desbiolles, F., \& Gifford, S. (2015). Sustainability through food and conversation: The role of an entrepreneurial restaurateur in fostering engagement with sustainable development issues. Journal of Sustainable Tourism, 23, 126-145.

Muller, H. (1994). The thorny path to sustainable tourism development. Journal of Sustainable Tourism, 2, 131-136. http://dx.doi.org/10.1080/09669589409510690.

Newcombe, R. (2003). From client to project stakeholders: A stakeholder mapping approach. Construction Management and Economics, 21, 841-848.

Parks and Wildlife Service (2001). Savage river national park management plan 20. Hobart, Tasmania: Tasmanian Parks and Wildlife Service, 01.

Phi, G., Dredge, D., \& Whitford, M. (2014). Understanding conflicting perspectives in event planning and management using Q method. Tourism Management, 40, 406-415.

Puczko, L., \& Ratz, T. (2000). Tourists and resident perceptions of the physical impacts of tourism at Lake Balaton, Hungary: Issues for sustainable tourism management. Journal of Sustainable Tourism, 8, 458-478. http://dx.doi.org/10.1080/ 09669580008667380.

Rogers, S. (1995). Rethinking methods in psychology. London: Sage.

Ryan, C. (2002). Equity, management, power sharing and sustainability: Issues of the 'new tourism'. Tourism Management, 23, 17-26. http://dx.doi.org/10.1016/S0261 5177(01)00064-4.

Salazar, N. (2012). Tourism imaginaries: A conceptual approach. Annals of Tourism Research, 39, 863-882.

Sautter, E., \& Leisen, B. (1999). Managing stakeholders: A tourism planning model. Annals of Tourism Research, 26, 312-328. http://dx.doi.org/10.1016/S0160-7383(98) 00097-8.

Schmolck P., Method Manual Q. (2009). 〈http//schmolck.userweb.mwn.de/qmethod/ pqmanual.htm $>$ Accessed 2/7/2014.

Stergiou, D., \& Airey, D. (2011). Q methodology and tourism research. Current Issues in Tourism, 14, 311-322. http://dx.doi.org/10.1080/13683500.2010.537316.

Southgate, C., \& Sharpley, R. (2002). Tourism, development and the environment. In R. Sharpley, \& D. Telfer (Eds.), Tourism and development concepts and issues (pp. 231262). Clevedon: Channel View Publications.

Sukarieh, M., \& Tannock, S. (2013). On the problem of over-researched communities: The case of the Shatila Palestinian Refugee Camp in Lebanon. Sociology, 47, 494-508. http://dx.doi.org/10.1177/0038038512448567.

Tasmania Parks and Wildlife Service. Savage River National Park (2014). 〈http://www. parks.tas.gov.au> Accessed 15 May 2014.

Timur, S., \& Getz, D. (2009). Sustainable tourism development: How do destination stakeholders perceive sustainable urban tourism? Sustainable Development, 4, 220-232. http://dx.doi.org/10.1002/sd.384.

Tourism Tasmania Corporate Website, Visitor statistics (2014). 〈http://www. tourismtasmania.com.au/research/visitors $>$ Accessed 12/12/2016.

Valenta, A., \& Wigger, U. (1997). Q methodology: Definition and application in health care informatics. Journal of America Medical Informatics Association, 4, 501-510. http://dx.doi.org/10.1136/jamia.1997.0040501.

Van Eeten, M. (1999). Dialogues of the deaf: Defining new agendas for environmental deadlocks. Delft, The Netherlands: Eburon Publishers.

Vernon, J., Essex, S., Pinder, D., \& Curry, K. (2005). Collaborative planning: Local sustainable projects. Annals of Tourism Research, 32, 325-345. http://dx.doi.org/10 1016/j.annals.2004.06.005.

Waligo, V., Clarke, J., \& Hawkins, R. (2013). Implementing sustainable tourism: A multistakeholder involvement management framework. Tourism Management, 36, 342-353.

Wesley, A., \& Pforr, P. (2010). The governance of coastal tourism: Unravelling the layers of complexity at Smiths Beach, Western Australia. Journal of Sustainable Tourism, 18(18:6), 773-792. http://dx.doi.org/10.1080/09669581003721273.

Westwood, S., Morgan, N., \& Pritchard, A. (2006). Situation, participation and reflexivity in tourism research: Furthering interpretive approaches to tourism enquiry. Tourism Recreation Research, 32, 33-34. 
Woodland, M., \& Acott, T.G, T. G. (2007). Sustainability and local tourism branding in England's South Downs. Journal of Sustainable Tourism, 15(6), 715-734.

World Commission on Environment and Development (1987). Our common future (Australian Edn). Melbourne: Oxford University Press.

Yuksel, F., Bramwell, B., \& Yuksel, A. (1999). Stakeholder interviews and tourism planning at Pamukkale, Turkey. Tourism Management, 20, 351-360. http://dx.doi. org/10.1016/S0261-5177(98)00117-4.

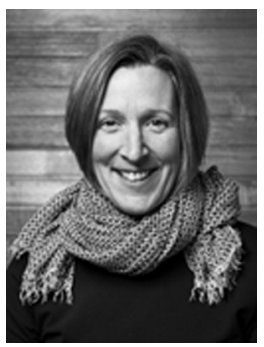

Dr. Anne Hardy is a Senior lecturer at the University of Tasmania. Anne's research interests are sustainable tourism, stakeholder management, and neo-tribal theory as a tool to explore the behaviour of tourists and leisure seekers. The majority of her research has been qualitative with a focus on the utilisation of inclusive and responsive mobile methodologies. Currently, Dr Hardy is leading a large international research team that will track the movement of self-drive tourists to Tasmania and explore their social media patterns.

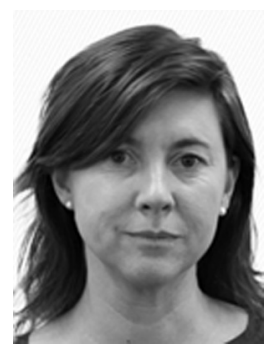

Dr Leonie Pearson is Leader, Major Research Projects (Economist) at the Regional Australia Institute and fellow at the University of Canberra. Leonie was originally trained as an economist, but has subsequently focused on regional and ecological economics. She has numerous publications in the fields of ecological economics and regional geography produced for academics, policy makers and practitioners. Leonie's interests focus on the economic and institutional drivers for communities to adapt and transform to achieve sustainable futures. 